\title{
Seroprevalence and associated risk factors for chlamydiosis, coxiellosis and brucellosis in sheep and goats in Borana pastoral area, southern Ethiopia
}

\author{
Asamenew Tesfaye ${ }^{1}$, Mesfin Sahele ${ }^{1}$, Teshale Sori ${ }^{2 *}$ (D, Chala Guyassa ${ }^{1}$ and Abebe Garoma ${ }^{1}$
}

\begin{abstract}
Background: Abortion is considered an important disease problem of small ruminants in Borana pastoral area. A cross-sectional study was conducted to estimate the prevalence and risk factors of chlamydiosis, coxiellosis (Q-fever) and brucellosis in small ruminants in selected districts of Borana zone.

Results: A total of 506 sheep and goats were tested using serological tests. Fifty (9.88\%; 95\% Cl: 7.42, 12.82), 144 (28.46\%; 95\% Cl: $24.56,32.61)$ and none $(0.00 \%$; $95 \%$ Cl: $0.00,0.59)$ of them were positive for chlamydiosis, coxiellosis and brucellosis, respectively. History of abortion was recorded in 136 (32.00\%; Cl: 27.59, 36.67) of sheep and goats in the study area. The logistic regression analysis, however, showed that statistically significant difference ccurred among districts and between the species of small ruminants. The prevalence odd of antibodies against C. abortus was significantly lower in Miyo, Dire and Teltelle districts compared to Dillo. The odd of infection with this bacterium was lower in sheep than goats. Similarly the odd of infection with C. burnettii was significantly higher in Dillo district than the rest of the districts studied, higher in goats than sheep and higher in adult animals than young ones.

Conclusion: High prevalence of abortion is observed in sheep and goats in the study area. High seropositivity of $C$. burnetii and C. abortus in both sheep and goats tested implies risks of human infection by both diseases. Thus, attention needs to be paid to further study of both diseases in animals and humans in the area.
\end{abstract}

Keywords: Borana, C. abortus, C. Burnettii, Brucella, Abortion, Sheep, Goats, Risk factors

\section{Background}

Abortion is one of the reproductive wastages causing considerable economic losses in small ruminants through loss of fetus and reduced milk production. Abortion in small ruminants is caused by various infectious agents $[1,2]$, the common ones being Chlamydophila abortus (C. abortus) [3, 4], Coxiella burnetii (C. burnetii) [5] and Brucella melitensis [6]. In addition to

\footnotetext{
* Correspondence: teshalesori2002@yahoo.com

${ }^{2}$ Collage of Agriculture and Veterinary Medicine, Addis Ababa University, P. O. Box, 34 Bishoftu, Ethiopia

Full list of author information is available at the end of the article
}

causing economic losses these diseases also cause human illnesses [7-9].

Chlamydiosis (also known as enzootic abortion) has been recognized since 1950 and is considered worldwide in distribution [10, 11]. Contaminated environment, water and feed are incriminated as source of infection for susceptible animals [12] although aerosol [13] and venereal [11] transmissions are possible. It has been documented that it causes abortion in 25 to $60 \%$ of naive sheep and goats in UK and North America. Abortion occurs in primiparous ewes and does during epizootics [14]. The prevalence of abortion was shown to be low in

(c) The Author(s). 2020 Open Access This article is licensed under a Creative Commons Attribution 4.0 International License, which permits use, sharing, adaptation, distribution and reproduction in any medium or format, as long as you give appropriate credit to the original author(s) and the source, provide a link to the Creative Commons licence, and indicate if changes were made. The images or other third party material in this article are included in the article's Creative Commons licence, unless indicated otherwise in a credit line to the material. If material is not included in the article's Creative Commons licence and your intended use is not permitted by statutory regulation or exceeds the permitted use, you will need to obtain permission directly from the copyright holder. To view a copy of this licence, visit http://creativecommons.org/licenses/by/4.0/ The Creative Commons Public Domain Dedication waiver (http://creativecommons.org/publicdomain/zero/1.0/) applies to the data made available in this article, unless otherwise stated in a credit line to the data. 
the first year and tend to increase during consecutive years as reported in countries such as Greece and Iran [15]. Epidemiological investigations showed that chlamydiosis occurs in $44 \%$ of diagnosed abortion cases in UK, in 56\% of the cases in Spain [16] and 69\% in Egypt [17].

Coxiellosis (also called Q-fever) is also one of the causes of abortion in small ruminants [18]. An infection with $C$. burnetii is usually latent in livestock though abortion storm as high as $60 \%$ has been documented in goats in Netherlands. The prevalence of abortion was $5 \%$ in sheep farms in the country [19]. Although it needs to be proved, ticks are incriminated for transmission of Qfever to susceptible hosts from wild and domestic animals reservoirs $[19,20]$. However, the transmission of Q-fever from livestock to humans is similar to that of brucellosis, including the consumption of unpasteurized dairy products, contact with aborted fetuses and other animal products (most often through respiratory and conjunctival routes). Antibodies to Q-fever were found in $54.2 \%$ of sera collected in Southeast Ethiopian pastoral goats [21].

Small ruminant brucellosis is a disease of economic and public health impact. It is mainly caused by Brucella melitensis (B. melitensis) both in sheep and goats [22, 23]. There are three biovars of $B$. meltensis that have differing geographic distribution, but no difference in pathogenicity or animal species affected [19]. Brucellosis in small ruminants is characterized by reproductive wastages such as abortion, stillbirth, birth of weak offspring and infertility [24]. Very low prevalence was reported in different parts of Ethiopia.

Although serological evidence of brucellosis and Qfever was reported in sheep and goats in Ethiopia, to our knowledge no study has been conducted on chlamydiosis so far. Sheep and goat production is very important activity in Borana pastoral area, where there has been empirical evidence of frequent occurrence of unconfirmed cases of abortion and stillbirth. It is difficult to obtain the magnitude of abortion in the pastoral areas due to lack of records. However, field veterinarians and livestock owners claim frequent occurrence of abortion in sheep and goats. Personal observations during the filed survey also confirmed this. Screening of animals for diseases causing abortion is important to design control methods. Since there is close contact with humans, the results of investigations also has important implications to human health. Therefore, the objective of this study was to screen sheep and goats in selected districts of Borana pastoral zone for Q-fever, chlamydiosis and brucellosis.

\section{Results}

Out the total of 506 sheep and goats tested 50 (9.88\%; 95\% CI: 7.42, 12.82), 144 (28.46\%; 95\% CI: $24.56,32.61)$ and none $(0.00 \%$; $95 \%$ CI: $0.00,0.59)$ of them were positive for chlamydiosis, coxiellosis and brucellosis, respectively. The proportion of animals testing positive for both chlamydiosis and coxiellosis was higher in adults. The difference between the age groups of animals was statistically significant for Coxiella infection although it was only marginally significant for Chlamydia infection. For both diseases the odd of infection was higher in Dire, Miyo and Teltelle districts than Dillo (Tables 1 and 2). The prevalence odd of antibodies against C. burnettii was significantly lower in Dire (half of Dillo), Miyo (nearly six times less than that of Dillo) and Teltelle (nearly one-third of Dillo). The odd of infection with this bacterium was 0.269 in sheep, which is nearly one-quarter of the odds of infection in goats. Similarly the odd of infection with $C$. abortus was significantly lower in Dire district $(\mathrm{OR}=$ 0.439 , which is half of Dillo), in Miyo district ( $\mathrm{OR}=0.267$, nearly one-quarter of Dillo) and Teltelle district ( $\mathrm{OR}=0$ .045 , which is $1 / 22$ the odds of infection in Dillo district). The seroprevalence was higher in goats $(\mathrm{OR}=2.2$ times that of sheep) and adult animals than young ones. However, there was no statistically significant difference between the two genders of the animals in terms of frequency of infection with both diseases.

Overall history of abortion was recorded in 136 (32.00\%; CI: 27.59, 36.67) of ewes and does in the study area. It was observed in 85 goats $(29.01 \%$; CI: 23.88 , $34.57 \%$ ) and 51 sheep (23.94\%; CI: $18.38,30.25 \%)$. Of these female animals with history of abortion 12 (8.82\%; CI: $4.64,14.91$ ) of them were positive for anti-C. abortus antibodies. In contrast anti- C. abortus was detected in 38 of 370 (10.27\%; CI: 7.37, 13.82) females with no

Table 1 The results of sero-prevalence of $C$. abortus infection in sheep and goats in Borana pastoral zone

\begin{tabular}{llllllll}
\hline Variables & № tested & Pos. & Percent & OR & $95 \%$ & $\mathrm{Cl}$ & $\boldsymbol{P}$-value \\
\hline District & & & & & & & \\
Dillo & 170 & 32 & 18.82 & & & & \\
Dire & 113 & 10 & 8.85 & 0.439 & 0.197 & 0.979 & $\mathbf{0 . 0 4 4}$ \\
Miyo & 130 & 7 & 5.38 & 0.267 & 0.107 & 0.666 & $\mathbf{0 . 0 0 5}$ \\
Teltelle & 93 & 1 & 1.08 & 0.045 & 0.006 & 0.337 & $\mathbf{0 . 0 0 3}$ \\
Species & & & & & & & \\
Goat & 293 & 33 & 11.26 & & & & \\
Sheep & 213 & 17 & 7.98 & 0.469 & 0.242 & 0.912 & $\mathbf{0 . 0 2 6}$ \\
Age & & & & & & & \\
Adult & 359 & 44 & 12.26 & & & & \\
Young & 147 & 6 & 4.08 & 0.417 & 0.160 & 1.087 & 0.074 \\
Sex & & & & & & & \\
Female & 424 & 41 & 9.67 & & & & \\
Male & 82 & 9 & 10.98 & 1.305 & 0.570 & 2.987 & 0.528 \\
Constant & & & & 0.345 & 0.207 & 0.575 & 0.000 \\
Total & $\mathbf{5 0 6}$ & $\mathbf{5 0}$ & $\mathbf{9 . 8 8}$ & & & & \\
\hline
\end{tabular}


Table 2 The results of seroprevalence of C. burnettii infection in sheep and goats in Borana pastoral zone

\begin{tabular}{llllllll}
\hline Variables & № tested & Pos. & Percent & OR & $95 \%$ & $\mathrm{Cl}$ & P-value \\
\hline District & & & & & & & \\
Dillo & 170 & 72 & 42.35 & & & & \\
Dire & 113 & 33 & 29.20 & 0.508 & 0.288 & 0.898 & $\mathbf{0 . 0 2 0}$ \\
Miyo & 130 & 17 & 13.08 & 0.175 & 0.090 & 0.338 & $\mathbf{0 . 0 0 0}$ \\
Teltelle & 93 & 21 & 22.58 & 0.317 & 0170 & 0.591 & $\mathbf{0 . 0 0 0}$ \\
Species & & & & & & & \\
Goat & 293 & 104 & 35.49 & & & & \\
Sheep & 213 & 39 & 18.31 & 0.268 & 0.166 & 0.433 & $\mathbf{0 . 0 0 0}$ \\
Age & & & & & & & \\
Adult & 359 & 123 & 34.26 & & & & \\
Young & 147 & 20 & 13.61 & 0.417 & 0.232 & 0.750 & $\mathbf{0 . 0 0 3}$ \\
Sex & & & & & & & \\
Female & 424 & 122 & 28.77 & & & & \\
Male & 82 & 21 & 25.61 & 1.158 & 0.625 & 2.148 & 0.641 \\
Constant & & & & 1.575 & 1.036 & 2.393 & 0.033 \\
Total & $\mathbf{5 0 6}$ & $\mathbf{1 4 4}$ & $\mathbf{2 8 . 4 6}$ & & & & \\
\hline
\end{tabular}

history of abortion. The occurrence of abortion was not statistically associated with serprevalence of $C$. abortus $(\mathrm{OR}=0$.69; CI: 0.34, 1.39). Animals having two or more parities were more prone to be seropositive than nulliparous animals although the difference was not statistically significant. Similarly out of a total of 136 females with history of abortion 38 (27.94\%; CI: 20.59, 36.28) of them tested positive for anti-C. burnettii antibodies whereas 99 of the 370 (26.76\%; CI: 22.31, 31.58) of females with no history of abortion gave positive results for anti-C. burnettii antibodies. The odds of seropositivity was 1.14 (CI: $0.72,0$ 1.79) higher in animals with history of abortion than those with no history of abortion. Seropositivity to $C$. burnettii was higher in animals having two or more parties $(\mathrm{OR}=2.18$; CI: $1.01,4.75)$ than nulliparous ones.

\section{Discussion}

This study was conducted in Borana pastoral area where small ruminants provide multitudes of financial, social and collateral services to the community. Hence, the $32 \%$ abortion observed has significant impact the livelihood of the pastoral community and the national economy. That is, abortions reduce replacement lambs and kids and affect the off take of young stock in light of the expanding abattoirs. Unless the knowledge, aptitude and practices of the pastoralists is improved, it can significantly affect the small ruminant industry. Optimum control of diseases causing abortion requires the understanding of their etiology and epidemiology. In this regard, we screened small ruminants for chlamydiosis, coxiellosis and brucellosis from selected districts of Borana pastoral area where abortion has been reported frequently. The study provided evidence of occurrence of chlamydiosis and coxiellosis in the area.

To the best of our knowledge this the first report of occurrence of infection with C. abortus in small ruminants in Ethiopia. The prevalence of anti- C. abortus antibody observed in sheep and goats in this study is in agreement with the report of Ghorbanpoor and colleague [25] who observed prevalence of $9 \%$ in sheep. However, the prevalence reported in this study is lower those reported elsewhere in the world such as that of José and colleague [26] from Brazil, Qudah and colleague [27] from Jordan, Esmaeili and colleague [28] from Iran and Vidal et al. [29] from Switzerland. Our result is also lower than the reports documented in in The Netherlands where $17 \%$ of abortion cases in goats were associated with Chlamydia species [30]. The difference observed in prevalence of chlamydiosis could be due to difference in the production system and the laboratory method used.

The results of logistic regression analysis showed that the seroprevalence of chlamydiosis is higher in goats than sheep. This could due to genetic variation in the predisposition to $C$. abortus between sheep and goats [31]. Statistically significant difference was also observed among districts. This might be ascribed to difference in local husbandry practices and frequency of contact with various flocks and herds as districts such as Dire, Teltelle and Miyo border Kenya, in which livestock movement in search of pasture and water is frequent. This movement can introduce and spread diseases. In addition there is a big livestock market in Dire different animals species are marketed. In this market place small ruminants from different districts in Borana zone and some neighboring districts of Kenya gather together weekly. This might have favored spread of the bacteria among animals, which made the prevalence to be higher. In contrast, Teltele, where the lowest prevalence was observed is found further from the market center. This is in agreement with the previous reports of Qudah et al. [27] who also observed significant difference in the seroprevalence of $C$. abortus infection among different locations.

The first evidence of occurrence of infection of Ethiopian livestock with $C$. burnetii dated back to the reports of Philip et al. [32] who observed seropositive cattle, sheep and goats. Later investigation carried out in pastoral livestock population revealed seroprevalence of $54.20 \%$ in goats [21]. This is higher than the prevalence reported in this study. The difference observed could be due to difference in study animals used. The previous authors used randomly selected animals that were seropositive to brucellosis, whereas we sampled animals from 
the general small ruminant population. However, studies conducted elsewhere in Africa and in the world are in agreement with our observation. For instance seroprevalence in the range of 23 to $33 \%, 15$ to $33 \%$ and $24 \%$ has been documented in Egypt, Morocco and Sudan, respectively [31].

Similarly seroprevalence ranging from 24.66 to $31.97 \%$ [33] and 29.80 to $36.50 \%$ [34] has been reported in small ruminants from Iran. Vandenburg and colleague [31], however, reported lower prevalence ranging from 7 to $12 \%$ in Tunisia and $11 \%$ in Ghana. That is, infection with C. burnetii (Q fever) is widespread in the world with varying prevalence. The variation in prevalence among countries highlights the importance of understanding risk factors which may operate at a local scale. The seroprevalence of infection with $C$. burnetii varies significantly among districts for similar reasons described above. In consent to our observation similar difference in the prevalence of $\mathrm{Q}$ fever has been reported among localities by Nakoune et al. [35] from Central African Republic. Significant difference has also been reported between adult and young animals and between species of animals [21]. The higher prevalence in goats than sheep could be due to genetic susceptibility or host preference of tick vectors although this observation needs to be further elucidated. The higher prevalence in adults can be ascribed to cumulative effects of age in which older animals became exposed to the vectors and acquire $C$. burnetii infection to which they develop antibodies.

The low seroprevalence of brucellosis observed in this study is remarkable considering the high prevalence reported previously in pastoral herds of goats in south eastern Ethiopia. Since only 506 animals from three districts were sampled positive animals might have been missed in the prevalence in the herds or flocks is low. On the other hand it is becoming a general trend for bovine brucellosis to be very low in Ethiopia [36].

\section{Conclusion}

High prevalence of abortion is observed in sheep and goats in the study area. High seropositivity of C. burnetii and $C$. abortus in both sheep and goats tested implies risks of human infection by both diseases. Thus, attention needs to be paid to further study of both diseases in animals and humans in the area. Since our study is a cross-sectional serological survey, the observed abortion in seropositive animals does not imply that $C$. burnetii and $C$. abortus have caused the abortion. This needs to be elucidated from longitudinal studies.

\section{Methods}

\section{Study areas}

The study was conducted in Borana pastoral districts in Borana zone, southern Oromia, Ethiopia. Borana zone is located between $3^{\circ} 36^{\prime}-6^{\circ} 38^{\prime}$ North latitude and $3^{\circ} 43^{\prime}$ $39^{\circ} 30^{\prime}$ East longitude in southern Ethiopia bordering Kenya. The zone is divided into 13 districts covering a total area of $48,360 \mathrm{~km}$. Borana Zone has a total population of 962,489 in a total of 182,258 households making an average of 5.28 persons to a household. The zone is characterized by a semiarid to arid climate. The altitude of Borana zone ranges from 1000 to $1700 \mathrm{~m}$ above sea level featured by isolated mountains and valleys. The mean annual rainfall of the area ranges from 250 to 700 $\mathrm{mm}$. The annual mean temperature varies from 19 to over $25^{\circ} \mathrm{C}$. Extensive pastoralism (nomadic pastoralism) is the main means of livelihood for the Borana people [37]. Cattle, goats, sheep and camels are important livestock species raised in the area. Four districts namely Dillo, Dire, Mio and Teltele (Fig. 1) were selected purposively for this study. They were selected because there was frequent abortion in both sheep and goats as reported by field veterinarians and also from personal observation during the field survey. The districts are bordered by Kenya and there is a big market in Dire where ruminants are marketed from adjacent districts of Borana and Kenya. That is, there is frequent movement of animals in the area in search of market and pasture.

\section{Study design and sampling}

A cross-sectional study was conducted in sheep and goats from the selected districts. The sample size required was computed using the formula described by Thrusfield [38]. No pre-specified prevalence considered for each pathogen since no previous study has been undertaken in the area. To increase the number animals we assumed the expected prevalence to be $50 \%$. According to the formula a minimum of 384 animals (192 sheep and 192 goats) were needed considering both species as one epidemiological unit. However, since sufficient collection materials and reagents were available the number was increased to 293 goats and 213 sheep making a total of 506 samples. Eighty-two of the study animals were male whereas 424 of them were female. A three-stage sampling method was employed in which the study districts were selected purposively as described above. This was followed by random selection of villages among all villages registered under the selected districts. From each district four villages were selected randomly. From each villages four farms (properties) having more than 10 sheep and goats aged greater than 3 months were selected from four villages. None of the animals in the study area were vaccinated against any of the diseases studied as there are no vaccines used against these diseases in Ethiopia.

\section{Blood sample collection}

Approximately 5-7 $\mathrm{mL}$ of blood samples were collected from jugular vein each sheep and goat for serological 


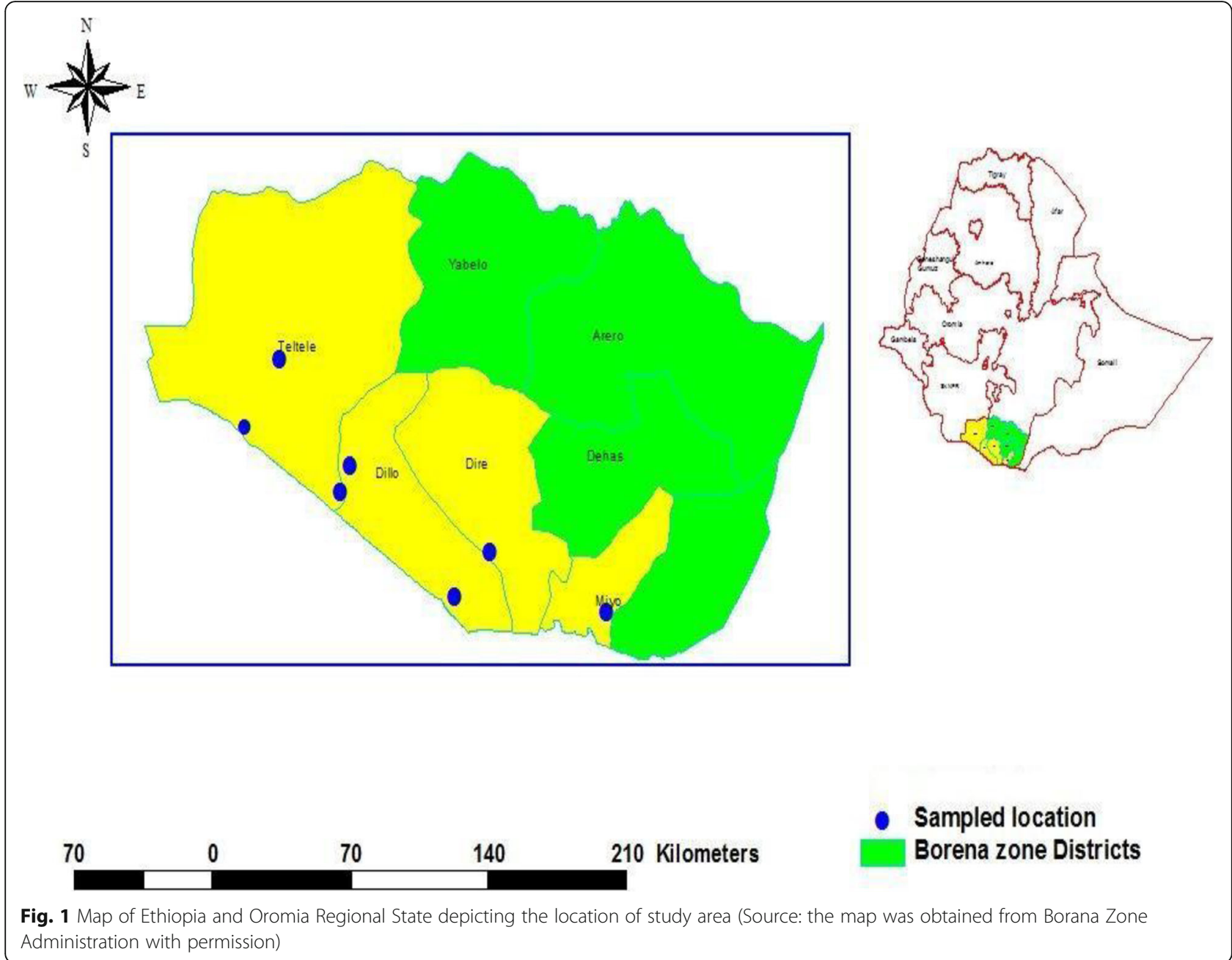

examination using sterile plain vacutainer tubes and needles following the necessary ethics described under the ethical declaration section. The tubes were labeled individually and were kept in icebox and transported to Yabello Pastoral and Dryland Agriculture Research Center. The samples were allowed to stand overnight to allow serum separation. The sera were separated after centrifugation at $1500 \mathrm{~g}$ for $10 \mathrm{~min}$. The sera were then collected into sterile cryogenic tubes and stored at $20^{\circ} \mathrm{C}$ until transportation to National Animal Health Diagnostic and Investigation Center, Sebeta, Ethiopia for analysis. The shipment of the samples was done using an ice box with ice pack. Various variables such as flock size (count), animal species (binary), flock composition, age (binary; as adult and young) and sex of animals (binary), location, number of pregnant animals (count), occurrence of abortion (binary) and stillbirth (binary) were recorded during blood collection by the investigators. Information on some of the variables such as abortion, stillbirth and age of animals were obtained from the owners.

\section{Laboratory analysis of samples Chlamydiosis}

Enzyme linked immunosorbent assay (ELISA) A commercial indirect ELISA was used to detect antibodies against C. abortus at National Animal Health Diagnostic and Investigation Center (NAHDIC), Sebeta, Ethiopia having sensitivity and specificity of 96.8 and $100 \%$, respectively [39]. The test was conducted in microplate coated with inactivated antigen following manufacturer's instruction. One hundred $\mu \mathrm{L}$ of pre-diluted sera and controls (1:400) were added into microtiter plate and incubated for one hour at $37^{\circ} \mathrm{C}$. The plate was then washed 3 times. Then $100 \mu \mathrm{L}$ of conjugate was added to each well followed by covering of the plates before incubating it for $1 \mathrm{~h}$ at $37^{\circ} \mathrm{C}$. The plates were washed 3 times. Finally $100 \mu \mathrm{L}$ of substrate was added to each well and incubated at $18-26^{\circ} \mathrm{C}$ for $15 \mathrm{~min}$. Then $100 \mu \mathrm{L}$ of stop solution was added to each well and the result was read at a wavelength of $450 \mathrm{~nm}$. The test is valid if the mean Optical density (OD) for negative controls 
$(\leq 0.500)$, positive control $(\leq 2.00)$ and the difference between them $(\geq 0.300)$. Sample to positive ratio $(S / P \%)$ was computed as the difference between the sample absorbance and the absorbance of negative control divided by the difference between absorbance of positive and negative controls and multiplied by 100 . The result is interpreted as negative if $\mathrm{S} / \mathrm{P}$ ratio is $<30$, suspected if $\mathrm{S} / \mathrm{P}$ ratio is $\geq 30$ but $<40$ and positive if $\mathrm{S} / \mathrm{P}$ ratio is $\geq 40$. Both positive and negative controls were provided along with the kits and validation was carried out as described by the manufacturers of the kit.

\section{Brucellosis}

Rose Bengal plate test (RBPT) All sera samples collected were initially screened by RBPT using RBPT antigen (Animal and Plant Health Agency, New Haw, Addlestone, Surrey, KT15 3NB, United Kingdom) according to OIE procedures [5]. Briefly, RBT antigen $(30 \mu \mathrm{L})$ was added onto a glass slide next to $90 \mu \mathrm{L}$ of sheep and goat sera. The antigen and test serum were mixed thoroughly in a plastic applicator, shaken for 4 min, and agglutination was read immediately. Any observed agglutination by the naked eye was considered to be a positive reaction.

Complement fixation test (CFT) All samples that were RBPT-positive were further subjected to complement fixation test as aconfirmatory test at the National Veterinary Institute (NVI), Bishoftu, Ethiopia. The Brucella antigen and control sera (positive and negative) used during the test were produced by Veterinary Laboratory Agency, UK. The standardization of the antigen was made at 1:20 working dilution (strength). The Brucella antigen, complement and 3\% sensitized sheep red blood cells were added after the test sera were serially diluted $(1: 5,1: 10,1: 20$, and $1: 40)$ in microtitre plates. Then the plates were incubated at $37^{\circ} \mathrm{C}$ for $30 \mathrm{~min}$. The test was considered positive when the reading was as partial fixation (50\% haemolysis) or complete fixation (no haemolysis) at 1:10 dilution. The validity of the test was considered when there was complete hemolysis in negative control serum and the positive control shows inhibition of hemolysis.

Although the sensitivity and specificity of both tests are lacking in tropical settings, the values for these parameters were considered from reports made elsewhere in the world. Hence, for RBPT: sensitivity ranges from 91 to $100 \%$ in affected areas [40], and from 96.7 to $100 \%$ on Brucella-free farms [41]; specificity from 95 to $99 \%$ in affected areas [40], and from 79 to $91.9 \%$ on Brucellafree farms [41] - for the CFT: sensitivity from 96.7 to $100 \%$ and specificity from 88.8 to $97.7 \%$ [41].

\section{Coxiellosis}

For detection of antibodies against Coxiella burnettii in sera samples a commercial enzyme-linked immunosorbent assay was used following the manufacturer's instruction. The test has a very high sensitivity and specificity as reported by the manufacturer [42]. Briefly sera samples, negative and positive controls were diluted at 1/400 using wash solution. The control samples (provided along with the kits) were dispended into duplicate wells whereas the sera samples were added to the remaining wells and the plate covered and shaken gently before it was incubated for 60 minutesat $37^{\circ} \mathrm{C}$ in humid chamber. The wells were emptied and washed three times with $300 \mu \mathrm{L}$ of wash solution and $100 \mu \mathrm{L}$ of conjugate was added and incubated as described above. The content of the plate was discarded and washed three times with $300 \mu \mathrm{L}$ of wash solution and $100 \mu \mathrm{L}$ of substrate was added. The plate was incubated at room temperature for $15 \mathrm{~min}$ and $100 \mu \mathrm{L}$ of stop solution and the result was read at $450 \mathrm{~nm}$ wavelengths. Validation of the test, computation of sample to positive ration and final interpretation of the result was performed as described above.

\section{Statistical analysis}

The effects of various variables such as district, species, age (categorized as young and adult), sex and parity on seropositivity to $C$. abortus and C. burnetii was analyzed by multivariable logistic regression analysis using STATA Version 13 (StataCorp, 4905 Lakeway Drive, College Station, Texas 77,845 USA). Since our outcome variables were binary the logit link was used to model the association between the occurrence diseases as a function of various predictors. The logistic display function was used to compute odds ratio from the model coefficients to estimate the effect size. The parameters describing relationship between predictors and sero-prevalence was estimated using maximum likelihood estimation method. Mixed-effects logistic regression was used to assess if clustering effect has occurred due to district and farms but there was no clustering effect. The effects of parity and abortion on seroprevalence were analyzed only for female animals. In all cases differences observed were considered statistically significant when $P<0.05$.

\section{Abbreviations \\ CFT: Complement Fixation Test; Cl: Confidence Interval; ELISA: Enzyme Linked Immunosorben Assay; NAHDIC: National Animal Health Diagnostic and Investigation Center; NVI: National Veterinary Institute; OD: Optical Density; OIE: World Organization for Animal Health; OR: Odds Ratio; RBPT: Rose Bengal Plate Test; S/P: Sample to Positive Ratio}

\section{Acknowledgements}

We would like to thank the Borana zone administration office for its willingness to collaborate with us while we were collecting data from sheep and goats from different districts. Our special thanks is also extended to Yabello Regional Veterinary Laboratory for their support during sample collection. The pastoralists also deserve special thanks for collaboration. 


\section{Authors' contributions}

A T and C G collected all the required data. M S and A G did the laboratory analysis and edited the paper. T S analyzed the data and prepared the draft of the paper. A T edited the paper. The authors have read and approved the manuscript for publication.

\section{Funding}

Not Applicable.

\section{Availability of data and materials}

All data generated and analyzed during this study are included in Tables 1 and 2. However, the raw data is available from the corresponding author upon reasonable request.

\section{Ethics approval and consent to participate}

Ethical clearance for this study was obtained from Addis Ababa University, College of Veterinary Medicine and Agriculture (AAU-CVMA), Minutes of Animal Research Ethics and Review committee. Before conducting the research, pastoralists were informed with the objectives of the study and consent was obtained from the household representative. The consent of the pastoralists was verbal because they are unable to write and read. Besides, they have their own traditional leadership, who manages such agreement in collaboration with the local administration. Their verbal agreement was recorded and approved by the committee.

\section{Consent for publication}

Not applicable.

\section{Competing interests}

The authors declare that they have no competing interests.

\section{Author details}

${ }^{1}$ National Anima Health Diagnostic and Investigation Center (NAHDIC), P. O. Box 04, Sebeta, Ethiopia. ${ }^{2}$ Collage of Agriculture and Veterinary Medicine, Addis Ababa University, P. O. Box, 34 Bishoftu, Ethiopia.

\section{Received: 15 January 2019 Accepted: 7 May 2020}

\section{Published online: 20 May 2020}

\section{References}

1. Givens MD, Marley MS. Infectious causes of embryonic and fetal mortality. Theriogenol. 2008;70:270-85.

2. Holler LD. Ruminant abortion diagnostics. The veterinary clinics of North America. Food Anim Pract. 2012;28:407-18.

3. Da Silva FG, De Freitas JC, Muller EE. Chlamydophila abortus in production animals. Cienc Rural. 2006:36:342-8.

4. Jee JB, Degraves FJ, Kim TY, Kaltenboeck B. High prevalence of natural Chlamydophila species infection in calves. J Clin Microbiol. 2004:42:5664-72.

5. OIE. Brucellosis. In: Manual of diagnostic tests and vaccines for terrestrial animals; 2016. Available at: http://www.oie.int/fileadmin/Home/eng/ Healthstandards/tahm/2.01.04_Bbrucellosis.pdf. Accessed 21 Dec 2018.

6. WHO (World Health Organization). Brucellosis in humans and animals; 2006 WHO/CDS/EPR/2006.7. p. 10.

7. Abd El-Razik KA, Al-Humiany WM, Ahmed AMA, Elfadaly BHA. Investigations on non brucella abortifacients in small ruminants in Saudi Arabia with emphasis on zoonotic causes. Global Veterinaria. 2011;6:25-32.

8. Abdel Hamid NH, Ebeid MH, Arnaout FK, Elgarhy MM, Elbauomy EM Ahmed HA, et al. Serological and bacteriological monitoring of ruminant brucellosis in seven governorates with control program follow-up in three cattle farm. Benha Vet Med J. 2012;23:254-63.

9. Abu-Dalbouh MAA, Ababneh MM, Giadinis ND, Lafi SQ. Ovine and caprine toxoplasmosis (toxoplasma gondii) in aborted animals in Jordanian goat and sheep flocks. Tropl Anim Health Prod. 2012:44:49-54.

10. Sache $K$, Hotzel H, Silckers P, Ellinger T, Ehricht R. DNA microarray-based detection and identification of chlamydia and Chlamydophila spp. Mol Cell Probes. 2005:19:41-50.

11. Longbottom D, Fairley S, Chapman S, Psarrou E, Vretou E, Livingstone E. Serological diagnosis of ovine enzootic abortion by enzyme-linked immunosorbent assay with a recombinant protein fragment of the polymorphic outer membrane protein POMP90 Chlamydophila abortus. J Clin Microbial. 2002:40:4235-43.
12. Aitken ID. Chlamydial abortion. In: Diseases of sheep. 3rd ed. Oxford: Blackwell Science Press; 2007.

13. Rodolakis A, Salinas J, Papp J. Recent advances on ovine chlamydial abortion. Vet Res. 1998;29:275-88.

14. Misty A, Edmondson JF, Roberts AN, Bychawski BS, Pugh DG. Theriogenology of sheep and goats. 2nd ed; 2012. p. 150-230. https://doi. org/10.1016/B978-1-43772353-3.10008-3

15. Barati S, Moori-Bakhtiari N, Najafabadi MG, Momtaz H, Shokuhizadeh L. The role of zoonotic chlamydial agents in ruminants abortion. Iran J Microbiol. 2017:9:288-94.

16. Everett KDE. Chlamydia and Chlamydiales: more than meets the eye. Vet Microbiol. 2000;75:109-26.

17. Anderson IE, Baxter SIF, Dunbar S, Rae AG, Philips HL, Clarkson MJ, et al. Analyses of the genomes of chlamydial isolates from ruminants and pigs support the adoption of the new species chlamydia pecorum. Int I Syst Evol Microbiol. 1996;46:245-51

18. Jorgen SA. Coxiella burnetii associated reproductive disorders in domestic animals-a critical review. Acta Vet Scand. 2013;55:13. https://doi.org/10.1186/ 1751-0147-55-13.

19. Constable PD, Hinchcliff KW, Done SH, Grunberg W. Veterinary medicine. A textbook of the diseases of cattle, horses, sheep, pigs, and goats. 11th ed. Missouri: Elsevier; 2017. p. 1791-3.

20. Johnson SAM, Kaneene JB, Asare-Dompreh K, Tasiame W, Mensah IG, Afakye $\mathrm{K}$, et al. Seroprevalence of $\mathrm{Q}$ fever in cattle sheep and goats in Volta region of Ghana. Vet Med Sci. 2019:5:402-11.

21. Gumi B, Rebuma F, Lawrence Y, Teshale S, Tadele T, Abraham A, et al. Seroprevalence of brucellosis and Q-fever in southeast Ethiopian pastoral livestock. J Vet Sci Med Diagn. 2013:2:1. https://doi.org/10.4172/23259590. 1000109.

22. OIE. Ovine and caprine brucellosis, Brucella melitensis. Manual of diagnostic tests and vaccines for terrestrial animals. Paris: Office international des Epizooties; 2009

23. Lilenbaum W, de Souza GN, Ristow P, Moreira MC, Fraguas S, Cardoso Vda S, et al. A serological study on Brucella abortus, caprine arthritis encephalitis virus and Leptospira in dairy goats in Rio de Janeiro. Vet J. 2007;173:408-12.

24. Radostits OM, Gay CC, Hinchcliff W, Constable D. Veterinary medicine, a text book of the diseases of cattle, horses, sheep, pigs and goats. 10th ed. Spain: Grafos, S.A. Arte Sobre Papel; 2007.

25. Ghorbanpoor M, Goraninejad S, Heydari R. Serological study on enzootic abortion of ewes in Ahvaz. Iran J Anim Vet Adv. 2007:10:1194-6.

26. José WP, Rinaldo AM, Rosa MP, Andréa AFO, Aline MS, Sílvio ROA, et al. Seroprevalence of antibodies to Chlamydophila abortus in ovine in the state of Alagoas. Brazil Braz J Microbiol. 2010;41. https://doi.org/10.1590/ S151783822010000200015.

27. Al-Qudah KM, Sharif LA, Raouf RY, Hailat NQ, Al-Domy FM. Seroprevalence of antibodies to Chlamydophila abortus shown in Awassi sheep and local goats in Jordan. Vet Med - Czech. 2004:49:460-6.

28. Esmaeili H, Bolourchi M, Mokhber-Dezfouli MR. Seroprevalence of Chlamydia abortus infection in sheep and goats in Iran. Iranian J Vet Med. 2015:9(2):73-7.

29. Vidal S, Kegler K, Greub G, Aeby S, Borel N, Dagleish MP, et al. Neglected zoonotic agents in cattle abortion: tackling the difficult to grow bacteria. BMC Vet Res. 2017;13(1):373. https://doi.org/10.1186/s12917-017-1294-y.

30. van den Brom R, Lievaart-Peterson K, Luttikholt S, Peperkamp K, Wouda W, Vellema P. Abortion in small ruminants in the Netherlands between 2006 and 2011. Tijdschr Diergeneeskd. 2013;137(7):450-7.22.

31. Vanderburg S, Rubach MP, Halliday JEB, Cleaveland S, Reddy EA, et al. Epidemiology of Coxiella burnetii infection in Africa: a one health systematic review. PLoS Negl Trop Dis. 2014;8(4):e2787. https://doi.org/10.1371/journal. pntd.0002787.

32. Philip CB, Hoogstraal H, Reiss-Gutfreund R, Clifford CM. Evidence of Rickettsial disease agents in ticks from Ethiopian cattle. Bull Wld Hlth Org. 1966:35:127-31.

33. Mobarez AM, Amiri FB, Esmaeili S. Seroprevalence of $Q$ fever among human and animal in Iran; a systematic review and meta-analysis. PLOS Neg Trop Dis. 2017. https://doi.org/10.1371/journal.pntd.0005521.

34. Rad KN, Azizzadeh M, Taghavi Razavizadeh AR, Mehrzad J, Rashtibaf M. Seroepidemiology of coxiellosis (Q fever) in sheep and goat populations in the northeast of Iran. Iranian J Vet Res. 2014;15(1):1-6.

35. Nakoune'a E, Debaereb O, Koumanda-Kotogneb F, Selekona B, Samorya F, Talarmin A. Serological surveillance of brucellosis and Q fever in cattle in the Central African Republic. Acta Trop. 2004;92:147-51. 
36. Edao BM, Hailegebreal G, Berg S, Zewude A, Zeleke Y, Teshale S, et al. Brucellosis in the Addis Ababa dairy cattle: the myths and the realities. BMC Vet Res. 2018;14:396. https://doi.org/10.1186/s12917018-1709-4.

37. Teshome D, Teshale S, Sacchini F, Wieland B. Epidemiological investigations of contagious caprine pleuropneumonia in selected districts of Borana zone , southern Oromia , Ethiopia. Trop Anim Hlth Prod. 2018;51(3). https://doi. org/10.1007/s11250-018-1744-y.

38. Thrusfield M. Veterinary epidemiology. In: Principles and methods. 4th ed. Chichester: Wiley; 2018. p. 275-84.

39. Wilson K, Livingstone M, Longbottom D. Comparative evaluation of eight serological assays for diagnosing Chlamydophila abortus infection in sheep. Vet Microbiol. 2008;135(1-2):38-45.

40. Faye B, Castel V, Lesnoff M, Rutabinda D, Dhalwa S. Tuberculosis and brucellosis prevalence survey on dairy cattle in Mbarara milk basin (Uganda). Prev Vet Med. 2005;67(4):267-81.

41. Mainar-Jaime RC, Muñoz PM, de Miguel MJ, Grilló MJ, Marin CM, Moriyón I, et al. Specificity dependence between serological tests for diagnosing bovine brucellosis in Brucella-free farms showing false positive serological reactions due to Yersinia enterolitica O:9. Can Vet J. 2005;46(10):913-196.

42. Emery PM, Ostlund EN, Schmitt BJ. Comparison of Q fever serology methods in cattle, goats, and sheep. J Vet Diagn Invest. 2012;24(2):379-82.

\section{Publisher's Note}

Springer Nature remains neutral with regard to jurisdictional claims in published maps and institutional affiliations.

Ready to submit your research? Choose BMC and benefit from:

- fast, convenient online submission

- thorough peer review by experienced researchers in your field

- rapid publication on acceptance

- support for research data, including large and complex data types

- gold Open Access which fosters wider collaboration and increased citations

- maximum visibility for your research: over $100 \mathrm{M}$ website views per year

At $\mathrm{BMC}$, research is always in progress.

Learn more biomedcentral.com/submissions 